\section{Do experiential events create city brand?}

\author{
Natalia Vila López ${ }^{1}$ \\ Inés Kuster Boluda ${ }^{1}$ \\ ${ }^{1}$ University of Valencia, Faculty of Economics, Marketing \\ and Market Research, Valencia, Spain \\ J. Trinidad Marín Aguilar ${ }^{2}$ \\ ${ }^{2}$ Autonomous University of Aguascalientes, Center of Economics \\ and Administrative Sciences, Department of Marketing, Aguascalientes, Mexico
}

Received on

07/02/2015

Approved on

05/23/2016

Responsible editor:

Prof. Dr. Guilherme de Farias

Shiraishi

Evaluation process:

Double Blind Review

\begin{abstract}
Purpose - This article analyzes to what extent mega-events are capable of developing powerful city brands that are internationally recognized - a topic that has been little studied to date.
\end{abstract}

Design/methodology/approach - We used the quantitative method. We carried out 398 surveys with citizens living in Aguascalientes (Mexico), during the mega-event known as the Feria Nacional de San Marcos.

Findings - The results allow us to verify that (i) with regard to background: residents' attitudes towards a city brand improve following experiences in mega-events in that city $(\mathrm{H} 1)$ and (ii) with regard to effects: improving city brand attitudes increases residents' quality of life (H2).

Originality/value - To date, there is no literature investigating how experiences in cultural mega-events improve attitudes towards city brands and, consequently, improve quality of life. To fill this gap, this article investigates the great advantages which mega-events can bring to a city

Keywords - Mega-events; city brands; quality of life; residents.

\title{
91
}




\section{Introduction}

Cities are perhaps the places in which the intersection of economic, social and environmental interests, actions and conflicts are most intensely expressed (La Roca and Ferrer 2004). Jessop and Sum (2000) characterize cities, or entrepreneurial metropolitan areas, as those which implement proactive strategies when positioning themselves in the international scenario, thus creating cities which are attractive for tourism and investment, for example (Kavaratzis 2004).

The "city brand" concept is relevant because there are more and more reasons for cities to manage and control their images as brands (Kotler et al. 2004); the need to attract tourists, factories, businesses and talented people, the urgency in finding markets for exports (Dinnie, 2004), or the importance of increasing their citizens' satisfaction (Zenker et al. 2009) are but a few of them. Financial constraints, alongside local authorities' lack of knowledge and skills in effectively implementing and directing city brand strategies, leads them to frequently cooperate with other public and private institutions (Pascual-Esteve, 1999), with the ultimate aim of increasing the satisfaction of people living in a particular place (Zenker et al. 2009), as a result of a previously developed positive attitude towards the city brand (Merrilees et al. 2009).

Nowadays, different studies on marketing are giving increasing importance to experiences (Schmitt 1999; Kao et al. 2007), especially those that occur during mega-events (Ryan and Mizerski, 2010; Pitt et al. 2010; Dolles and Söderman, 2010). However, events' ability to develop powerful, globally recognized city brands has been poorly investigated in the literature (Rodriguez and Vila, 2013), justifying the need for further research.

Among the existing strategies for developing the city brand concept, there are two interrelated paths that have been widely investigated over recent years: experiential marketing and event marketing. That is, the development, in cities, of mega-events capable of arousing emotional experiences among citizens (Leonardsen, 2007; Dolles and Söderman, 2010) are seen as an alternative for leisure that is beneficial to citizens, translating into the consolidation of the city brand in which events occur. To date, studies addressing this issue have focused largely on emotions that sports events are capable of awakening (Kao et al. (2007); few have been concerned with addressing the effectiveness of other, cultural events. In any case, the goal is none other than the commitment to differentiation (building city brands), to demonstrate in this way that local governments can successfully manage their city brand if they choose to hold experiential events. This is because a good city brand translates, ultimately, into an improvement in the perception of quality of life among citizens (Kotler et al 2004; Kavaratzis, 2004; 2008).

In the described scenario, this article seeks to demonstrate whether a festive, experiential mega-event that arouses emotions (independent variable) is capable of directly improving city brand attitudes among participants who live in that city (dependent variable) and, ultimately, indirectly improving their quality of life (dependent variable). Thus, the mediator of improving brand city attitudes between experimentation of an experiential event and improving quality of life role arises.

To this end, we gathered information from 398 citizens in Aguascalientes (Mexico), who were personally interviewed while participating in the experiential mega-event known as Feria Nacional de San Marcos in its 2011 edition, from April 23 to May 10, while informants were involved in the event's various programs: sports, cultural, social, entertainment and nightlife. This information has allowed to contrast a model of structural relationships and analyzing raised by EQS technique to analyze the social perspective integrated from marketing such as a generator of perceived quality of life from its citizens. 


\section{Literature review}

Below, we review the relevance of the city brand concept, to then address how experiential marketing in general, and event marketing in particular, can contribute to generating city brands. All with the ultimate aim of increasing the quality of life of residents, a concept that is reviewed and related to the brand in the fourth and final section.

\section{I City brand}

The American Marketing Association defines (AMA, 1960) brand as "a name, term, design, symbol, or a combination of them, intended to identify the goods or services of one seller or group of sellers and to differentiate them from competitors". Applying techniques to create brands for nations, cities and places is increasing (Anholt, 2002, 2007; Hall, 2003; Dinnie, 2004; Kotler et al. 2004; Ponsonby-McCabe and Boyle, 2006;), given the strong global competition they face to retain industries and attract tourists (Dinnie 2004).

From a corporate perspective, brand strategis are similar among companies and cities, because the latter learn from the former, creating a gradual mutation in which business thinking is introduced in national institutions until they also become brands (Dinnie, 2004). The consolidation of the positive image of a country (or city) is as important as achieving a favorable position for a company (or brand) (Kotler et al 2004). This is due, to a large extent, to the immense competition that countries currently live to attract the largest possible number of tourists, since it generates wealth and development in popular tourist destinations (Dinnie, 2004; Kotler et al. 2004).

Lynch (1960) originally defined the term city brand as the perceived image of a city according to geographical aspects. In his study, Ward (1998) provides a historical review of how cities have been marketed as brands since 1850 , highlighting the role of the promotion variable in marketing strategy. In the same line, Ashworth and Voogd (1990) present the general principles of city brand and defend a marketing philosophy in all aspects concerning urban planning. In this regard, Smyth (1994) analyzes the marketing of cities, through their association with iconic urban regeneration events (Merrilees et al. 2009). Recently, urban studies have also been conducted in the same line, considering the relevance a place brand may acquire in attracting tourists and business (Merrilees et al. 2009).

In conclusion, literature on city brand has recognized the relevance of the concept "brand" linked to a particular geographical area, but has not quantified the possibility that the different stakeholders involved in a city develop different perceptions of the brand image (Fitchett, 2005; Friedman and Miles, 2002; Virgo and De Chernatony, 2006). To cover this gap, the concept "city brand attitude" has been gaining strength, and been recently used in the study by Merrilees et al. (2009). This paper modifies the traditionalist perspective of creating a city brand image as the orientation of rulers, and evaluates the attitude of residents in a city while trying to understand, in particular, what are the key background (city attributes) capable of positively influencing city brand attitudes needed to consolidate the city. These authors conceptualize the term "city brand attitudes" as "the deeper understanding of how branding works in this particular context and provides a framework by which local governments can manage and modify such attitudes for the public good" (Merrilees et al. 2009: 362).

\subsection{Experiential marketing}

The literature review has allowed to note that there are several factors that relate to the generation of positive city brand attitudes among residents of a particular place. In this sense, some authors have opted for the creation of experiential mega-events in strategic points in the city which generates a positive acknowledgment of this place (Pitt et al. 2010.; Dolles and Söderman, 2010). In other words, the positive experiences in megaevents (defined as experiential marketing tools) 
improve the attitude towards a particular city brand (Kavaratzis, 2008). That is, experiential marketing (understood through an event) recreates a subjective state of consciousness, with a variety of symbolic meanings, hedonic responses and aesthetic criteria (Holbrook and Hirschman, 1982), which means consumption event experiences.

The first authors who worked on the effects of experiential marketing coined the term "experiential consumption" (Holbrook and Hirschman, 1982). These authors proposed a model to explain the experiential purchase from the treatment of the information used for making decisions. Subsequently, the model was expanded to include value (Holbrook and Kim, 1985), cognition (Hirschman, 1985a), emotion (Holbrook, 1986) and global awareness (Hirschman, 1985a, 1985b) in experimental use.

To better understand the usefulness, for businesses, of creating pleasant experiences among consumers, it is necessary to understand the reasons why they acquire products and, further, why they want to have a unique experience with a certain brand. In reality, few human behaviors are as powerful as shopping (Puccinelli et al. 2009). Consumers buy for several reasons, which do not always include a special need for a good or service (Tauber, 1972, Puccinelli et al. 2009). For example, consumers look for entertainment, recreation, social interaction or intellectual stimulation (Arnold and Reynolds, 2003; Puccinelli et al. 2009). The construct of experiences is holistic in nature and involves the consumer in cognitive, emotional, social and physical responses (Verhoef et al. 2009). Experiential consumption itself generates value (Mathwick et al. 2001). The perception of experiential value is based on the interactions between the consumer and the goods and services (Mathwick et al. 2001).

Traditionally, literature interested in addressing the generation of experiences has centered on the point of sale as the "place" in which such experiences occur. From this perspective the emphasis is on the variable of distribution (Ibrahim and Wee, 2002). In this field, we have studied the atmosphere of the store and its impact on the senses, music, color effects on consumers and affective responses to traders (Naylor et al. 2008). The main findings suggest that experiences are not created only on the basis of the elements that companies can control, but also depend on what happens in the environment (Verhoef et al. 2009).

As a result, it is important to establish other means capable of building pleasant relationships between brands and their target audiences, beyond the establishments that sell such brands: event marketing (Whelan and Wohfeil, 2006). This orientation-based experiential marketing event begins to be considered particularly suitable for reaching the target audience involving them as "active participants" to a behavioral level (Rodriguez, 2010). According to the definitions by Ritchie and Yangzhou (1987), Law (1993) and Getz (1997), there are many types of marketing events applicable to an experiential level. These can be classified by size (number of visitors, level of media coverage, economic impact on the region, duration and frequency), season (cultural, sports, economic, social, socio-political, etc.) (Freyer, 2000) and its impact exerted on the image of the city in which they take place (low impact, medium impact, high impact) (Law, 1993; Dolles and Söderman, 2010).

\subsection{Event marketing}

Whelan and Wohfeil (2006) define event marketing as hyper-dimensional, interactive realities concerning the brand in which consumers are actively involved at a behavioral level, eventually attaining an emotional bond with the brand. Thus, experiential marketing through an event is differentiated from mere sponsorship at points listed in Table 1: 
Table 1

Differential characteristics of event marketing.

\begin{tabular}{|c|c|}
\hline Characteristic & Definition \\
\hline Orientation to the experience & $\begin{array}{l}\text { Consumers experience living under the brand actively, which subjectively increases their quality } \\
\text { of life (Weinberg and Nickel, 1998). }\end{array}$ \\
\hline Self-initiation by the organization & $\begin{array}{l}\text { The event to be created by the organization has the ability to control the impact on consumers } \\
\text { and therefore has full control of the experience to generate feelings toward the brand (Weinberg } \\
\text { and Nickel, 1998; Wohfeil and Whelan, 2004). }\end{array}$ \\
\hline Interactivity: & $\begin{array}{l}\text { There is a platform for interactive dialogue among participants in the event (participants, } \\
\text { spectators and brand representatives) actively (Zanger and Sistenich, 1996). }\end{array}$ \\
\hline Drama: & $\begin{array}{l}\text { Consumers emotionally live the reality of the brand through a unique drama that should be away } \\
\text { from the everyday and be put on a higher mark in the simple purchase (Zanger and Sistenich, } \\
\text { 1996; Sistenich, 1999) plane. }\end{array}$ \\
\hline
\end{tabular}

Note. Source: Adapted from de Whelan y Wohfeil (2006).

From a demand approach, and according to Kao et al. (2007), events that generate emotional experiences should be evaluated according to the surprise that is generated, the participation or interaction they produce between attendees, and the level of immersion that the event can develop with its target audience. Going to events generates different feelings among participants: happiness, surprise and entertainment, among others (Kao et al. 2007).

From a supply approach, and according to authors such as Sola (1998) and Roche (1994), mega-events also have an extraordinary impact on the region where they are held, in terms of one or more of the following dimensions: (i) increased volume of tourists, (ii) visitor spending, (iii) advertising development leading to greater awareness and a more positive image of the place, (iv) increased infrastructure and organizational capacity. All this substantially increases the destination's capacity and attraction for visitors, also making it a better place to live in from the perspective of residents themselves.

This distinction between effects of supply and demand is also manifested by Atkinson et al. (2008). Thus, for these authors, megaevents produce direct (supply) and indirect (demand) benefits. Direct benefits are not limited to attracting tourists boosting this industry, also contribute to increasing improving city infrastructure attracting new business from other business sectors. Indirect benefits are more connected to perceptions generated among participants, from the recognition of the image of the city to greater attention from the media (Ritchie and Yangzhou, 1987; Atkinson et al. 2008; Curi et al. 2011). Combining both effects, we highlight that the organization of a megaevent is a clear example of how to contribute to the economic development of the place in which it is performed, allowing to generate a positive image to that place, partly thanks to the coverage the media attach the event in situation and in partly thanks to the development of pleasurable experiences through tourism occur between residents and nonresidents (Curi et al. 2011).

Roche (2003) suggests that mega-events (including cultural, recreational, commercial and sports) have a dramatic feature, attractive and popular mass character and international significance. Often they are promoted by international governmental and non-governmental organizations (Roche, 2003) or local counting with the participation of citizens and government. In any case, all these types of events give rise to interesting effects for the city in which they are held, usually expressed between the feelings of the average citizen.

Either way, what matters is the ability of the event used to run experiential marketing in 
the consolidation of city brand that promotes the event. That is why the role of mega-events in consolidating brand images is a topic that is gaining interest, especially the sports mega-events. However, so far it has been studied only the impact exerted by this type of sports events (Curi et al. 2011) but not others (for example cultural).

As has been emphasized, the impact of mega-events to society can be as wide and varied as the types of mega-events existing. In this line, the present study seeks to determine to what extent emotional experiences in mega-events promoted by a particular city, are capable of producing pleasurable sensations that satisfy the desires of the attendees (Schmitt, 1999, Holbrook and Hirschman, 1982; Koa et al. 2007) and, consequently, improve the city brand attitude among participants (Merrilees et al. 2009).

This relationship has previously been shown in the literature in the study of Dolles and Söderman (2010), which postulates the participation of citizens in the experience of a mega-event (the World Cup in Germany 2006) as a source of enrichment of the city and recognition of their city as a brand. Specifically, the study of these authors emphasizes that the emotional experiences of the mega-event increased the value of the country brand. Experience that can translate to present study the characteristics of a city brand. Likewise, Mo et al. (1993), highlight the hospitality of the residents as a key to generate a pleasant experience in a destination (city brand), thereby achieving greater recognition among the residents themselves (city brand attitudes) like this towards the tourists and visitors. In the same line, recent studies show that the construction of a destination (city brand) can be generated based on cultural activities, entertainment and nightlife, the atmosphere of the city, trade and the number and type of events develop that destination (Zenker $e t$ al. 2009). The link between event (mega-event) and brand (city brand) has also been approached from the point of view of the image transfer from the event to the brand promoting/sponsoring the event (Küster et al. 2009).

In addition, previous studies indicate an important relationship between emotional experiences in mega-events and city brand attitudes in which they are held, so it is possible to establish the first hypothesis of this research:

H1: The emotional experiences in megaevents improve the city brand attitudes.

\subsection{Quality of life}

Experiential marketing through a megaevent would have a first direct effect on city brand attitudes and a second indirect effect on the perceived quality of life in the city.

Regarding the concept quality of life, the literature shows different meanings. For the term quality of life, literature shows different meanings. As for economists, quality of life means "economic welfare"; to psychologists, it is "a general feeling of well-being, life satisfaction, subjective wellbeing and happiness." For environmentalists, quality of life is "reforestation, air quality, clean water, wildlife preservation, etc." For consumers, it means "satisfaction, information, and customer protection." Managers of human capital define quality of life as "the quality of working life" (Sirgy et al. 1982; Sirgy, 2001). That is, the quality of life concept is elusive (Pennings, 1982); its definition and measurement are subject to debate from fields such as economics, sociology and geography, precisely because of the lack of a clear definition (Rogerson et al. 1988; Perry and Felce, 1995).

From the perspective of marketing, quality of life is equal to customer satisfaction with their welfare in every way (Sirgy et al. 1982; Sirgy, 2001). Many marketing scholars have linked the study of quality of life with the impact of satisfaction through various indicators (Sirgy et al. 1991), usually measured through the scale of "life satisfaction."

Traditionally, marketing managers have conceptualized marketing performance in terms of sales, profit, and market share targets in 
relation to a particular product over a period of time (Aaker, 1984; Day 1984). However, when looking only economic risk it is that marketing objectives are geared to financial growth, still likely to be acted incorrectly and irresponsibly socially speaking (Cespedes, 1993).

From the standpoint of marketing as a generator of quality of life, this philosophy seeks to develop products, services and marketing programs that can improve the welfare of consumers, to market products effectively and efficiently so that the effects are minimized side and negative among consumers and other audiences, while generating long-term benefits (Sirgy, 1996).

Some authors have linked quality of life with various marketing strategies, in which the main objective is to create better way of life among the citizens (Cuenca, 2000). It is understandable then that the quality of life remains presently a cornerstone in marketing studies and, the science of marketing increasingly strives to find alternatives to increase the human condition (Kilbourne et al. 1997).

In this regard, studies on city brand look the way to provide quality of life. The city brand has, on one hand, the basis for the development of policies to achieve economic development in an area, and, on the other hand, it serves as a conduit through which city residents identify themselves with the city (Kavaratzis, 2004). This does not mean that other audiences (visitors, investors, etc.) are considered less important, but it simply emphasizes the fact that all activities (economic, cultural, social, tourism or any other development of the city) are on behalf of residents of the city and among its objectives is to improve their quality of life (Kavaratzis, 2004).

Research by Kavaratzis (2008) in the section on the study of Athens, shows that the attitude among residents to Greece after the Olympic Games in 2004 became more favorable, becoming the Greeks in more extroverted citizens, more open-minded and more self-confidence
(Tatsiopoulos and Tziralis, 2007). That is, this event changed the attitudes of the Greeks to their country, triggering a sense of pride, which was reflected ultimately in an increase in their quality of life. Based on this study, it is possible to establish the following hypothesis of this research:

H2: City brand attitudes increase the quality of life among residents.

\section{Methodological design}

The purpose of this research is to clarify the relationship between emotional experiences in mega-events, the city brand attitudes and the quality of life by checking the two hypotheses together through structural equations.

In order to contrast the proposed model, it was decided to collect information on the mega-event Feria Nacional de San Marcos in its 2011 edition that takes place in the city of Aguascalientes, Mexico, from 183 years ago and in which $>85$ per cent of the events are free. This mega-event is known as La Feria de Mexico, because it received $>8$ million visitors during the exhibition period. The event is sponsored entirely by the Government of the State of Aguascalientes. Its internationalization began in 2010, following other major fairs of the world such as Seville in Spain, Nimes in France, Pomona in California and Calgary in Canada (Cifras, 2010).

The Feria Nacional de San Marcos is of paramount importance for the local economy since it generates an economic impact of more than $\$ 200$ million dollars; It promotes the presence of more than 7 million foreign showmen, achieving greater international projection made of Aguascalientes in Mexico and in the world; as well as generating an average of 6 thousand jobs during the mega-event (Cifras, 2010).

\section{I Measuring concepts}

The measuring instrument used in this research consists of 12 items Likert of five points. 
One item to discriminate against informants and six more to determine the profile of the sample used. In order to analyze the different concepts proposed by the literature, different scales were refined and adapted to the population under study by a group of experts in a previous qualitative phase were identified. The questionnaire used for data collection was based on an extensive review of the literature being structured as follows (Table 2):

\section{I.I City brand attitudes}

Items relating to the city brand attitudes were taken from previous scales on brand attitude (Delgado-Ballester and Munuera-Alemán, 2001; Taylor and Hunter, 2003) and adapted to a situation in the city (Merrilees et al. 2009). In addition, they were translated to Spanish for later application, once the qualitative research phase was concluded.

\subsubsection{Emotional experiences in mega-events}

The measurement scale of emotional experiences in mega-events has been retaken from the analysis by Kao, Huang and Yang (2007) reapplied to measure vivid experiences in a sports event. Its adaptation has been successful in the marketing of musical events (Rodriguez, 2010), and this is why it was also chosen for this study, with the adaptations referred to in the qualitative phase.

\subsubsection{Quality of life}

According to previous studies concerning quality of life (Flanagan, 1978; Fayers et al. 1997; Lloyd and Auld, 2002), an overall measure of quality of life was included in the model proposed by Baker and Palmer (2006): How satisfied are you with your quality of life in general? However, this study also used three additional items to statistically test the construct validity and thus evaluate the level of the individual's perception about their quality of life more widely. One reason was that the measurement of the overall quality of life for a single item (Fayers et al. 1997) was questioned, since the use of individual indicators has been shown to reduce the reliability of models and constructs (Bollen 1989; Fayers et al. 1997; Fayers and Machin, 2000; Bentler, 2005). Therefore, this research has used the four items used by Baker and Palmer (2006) to measure the quality of life that had a strong reliability coefficient (0.91).

\section{Table 2}

\section{Measuring concepts}

\begin{tabular}{|c|c|c|}
\hline \multicolumn{2}{|c|}{ City brand attitudes } & \multirow{3}{*}{$\begin{array}{l}\text { Resource } \\
\text { Merrilees et al. (2009) from Delgado- } \\
\text { Ballester and Munuera-Alemán } \\
\text { (2001); Taylor and Hunter (2003). }\end{array}$} \\
\hline CBA1 & I am proud to live in Aguascalientes & \\
\hline CBA2 & $\begin{array}{l}\text { Compared to the rest of the country, life in general is good in } \\
\text { Aguascalientes }\end{array}$ & \\
\hline CBA3 & I prefer living in Aguascalientes than elsewhere & \\
\hline CBA4 & The people of Aguascalientes have a good reputation at a national level & \\
\hline \multicolumn{2}{|c|}{ Emotional experiences in mega-events } & Resource \\
\hline EME1 & The events provide entertainment & \multirow[t]{4}{*}{ Kao et al. (2007) } \\
\hline EME2 & The events are great & \\
\hline EME3 & I am very happy with the environment within the perimeter of the fair & \\
\hline EME4 & I am very happy to experience "San Marcos 2011" & \\
\hline \multicolumn{2}{|c|}{ Quality of life } & Resource \\
\hline QOL1 & How satisfied are you with your quality of life? & \multirow{4}{*}{$\begin{array}{l}\text { Baker y Palmer, } 2006 \text { (new } 3 \\
\text { items). Based in Flanagan, 1978; } \\
\text { Fayers et al. 1997; Lloyd y Auld, } \\
\text { 2002). }\end{array}$} \\
\hline QOL2 & Are you satisfied with how you spend your free time? & \\
\hline QOL3 & How satisfied are you with your fitness level? & \\
\hline QOL4 & In general, how satisfied are you with your quality of life as a resident of Aguascalientes & \\
\hline
\end{tabular}




\section{Data analysis}

Thus, a sample of 398 individuals integrated $51.5 \%$ of women and the remaining $48.5 \%$ by men. It was also observed that their average age is between 19 and 29 years in accordance with the highest percentage localized (48.5\%), and it was observed that $51.3 \%$ remain single. The educational level has resulted in higher studies by $74.6 \%$; with high school education (23.1\%) and university (51.5\%). 66.1\% of the respondents are employed, while $22.9 \%$ of respondents are still students. The percentage of unemployed who attend this mega-event is low compared to unemployment rates in Mexico. Monthly income does not exceed $\$ 3,000$ pesos (220 USD) by $39.2 \%$ and only $25.1 \%$ have income in a range of $\$ 6,001$ to $\$ 10,000$ pesos (445-740 USD).

The scales and measuring instrument were subject to confirmatory factor analysis, in which all loads and " $t$ " values were significant at $\mathrm{p}<0.01$ value. Reliability was tested by three analyzes.
First, with Cronbach's a coefficient obtaining higher values .70 , so this criterion was accepted (Nunnally and Bernstein, 1994). Second, an analysis of composite reliability index obtaining higher values .80 was achieved (Carmines and Zeller, 1979). Finally, to determine the reliability also an analysis of the average variance extracted (AVE), in which the results were higher than .50 (Fornell and Larcker, 1981). Table 3 contains the results of confirmatory factor analysis study.

Once proven the reliability of the instrument, we proceeded to analyze the validity using for this purpose, tests confidence intervals. The results in Table 4 show that none of the confidence intervals (italics) include the value " 1 ". As for the average variance extracted test it is found that the values of the AVE (on the diagonal) are superior to the square of covariance (below the diagonal) between pairs of factors analyzed. Therefore, we can say that the measuring instrument measured what, indeed, was expected to be measured.

Table 3

Reliability and convergent validity of the measuring instrument.

\begin{tabular}{|c|c|c|c|c|c|c|}
\hline Factor & Indicator & Load & t Value & Cronbach's a & CR & AVE \\
\hline \multirow{4}{*}{ EME. Emotional experiences in mega-events } & EME1 & $0.689^{* * *}$ & 14.821 & \multirow{4}{*}{0.853} & \multirow{4}{*}{0.896} & \multirow{4}{*}{0.634} \\
\hline & EME2 & $0.722^{* * *}$ & 15.793 & & & \\
\hline & EME3 & $0.807^{* * *}$ & 18.429 & & & \\
\hline & EME4 & $0.854^{* * *}$ & 19.984 & & & \\
\hline \multirow{4}{*}{ CBA. City brand attitudes } & CBA1 & $0.821^{* * *}$ & 18.950 & \multirow{4}{*}{0.837} & \multirow{4}{*}{0.846} & \multirow{4}{*}{0.582} \\
\hline & $\mathrm{CBA} 2$ & $0.654^{* * *}$ & 13.938 & & & \\
\hline & CBA3 & $0.889^{* * *}$ & 21.264 & & & \\
\hline & CBA4 & $0.661^{* * *}$ & 14.134 & & & \\
\hline \multirow{4}{*}{ QOL. Quality of life } & QOL1 & $0.725^{* * *}$ & 15.188 & \multirow{4}{*}{0.799} & \multirow{4}{*}{0.806} & \multirow{4}{*}{0.512} \\
\hline & QOL2 & $0.812^{* * *}$ & 17.514 & & & \\
\hline & QOL3 & $0.659^{* * *}$ & 13.481 & & & \\
\hline & QOL4 & $0.654^{* * *}$ & 13.346 & & & \\
\hline
\end{tabular}

Notes: $\mathrm{N}=398{ }^{* * *} \mathrm{p}<.01 ;{ }^{* *} \mathrm{p}<.05 ;{ }^{*} \mathrm{p}<.10$; $\chi^{2}(\mathrm{p})=519.079(0.0000), d f=177 ; \mathrm{NNFI}=0.903 ; \mathrm{CFI}=0.918 ; \mathrm{IFI}=0.919 ; \mathrm{RMSA}=0.07$

Source: Authors 
Table 4

Discriminant validity and value intervals.

\begin{tabular}{lccc}
\hline & CBA & EME & QOL \\
\hline CBA & $\mathbf{0 . 5 8 2}$ & $(0.511 ; 0.671)$ & $(0.203 ; 0.419)$ \\
EME & 0.349 & $\mathbf{0 . 6 3 7}$ & $(0.271 ; 0.483)$ \\
QOL & 0.097 & 0.142 & $\mathbf{0 . 5 1 2}$ \\
\hline
\end{tabular}

Notes: Below the diagonal: estimated correlation between factors; Diagonal (bold): average variance extracted (AVE); Above the diagonal (italics): confidence intervals for the estimated correlations

Source: Authors

After checking the reliability and validity of the scales that make up the proposed model, we proceeded to make the model estimates a structural equation model using the robust maximum likelihood method for its ability to overcome variable non-normality problems (Bentler, 2005) by using the EQS 6.1 and SPSS 18 software; results are shown in Table 5. Goodness of fit statistics suggest that the structural model fits the data structure well.

Table 5

\section{Estimation of the planned model}

\begin{tabular}{llllcc}
\hline & Structural Relationship & \multicolumn{2}{c}{ b standardized } & t Value & Criterion \\
\hline H1 & Emotional Experiences in Mega-events à City brand Attitudes & 0.578 & $* *$ & 9.327 & It is accepted \\
H2 & City brand Attitudes à Quality of Life & 0.304 & $* *$ & 4.924 & It is accepted \\
\hline
\end{tabular}

Notes: $\mathrm{N}=398^{* *} \mathrm{p}<.01 ; \chi^{2}(\mathrm{p})=536.523(0.0000), d f=179 ; \mathrm{NNFI}=0.900 ; \mathrm{CFI}=0.915 ; \mathrm{IFI}=0.915 ; \mathrm{RMSA}=0.071$

Source: Authors

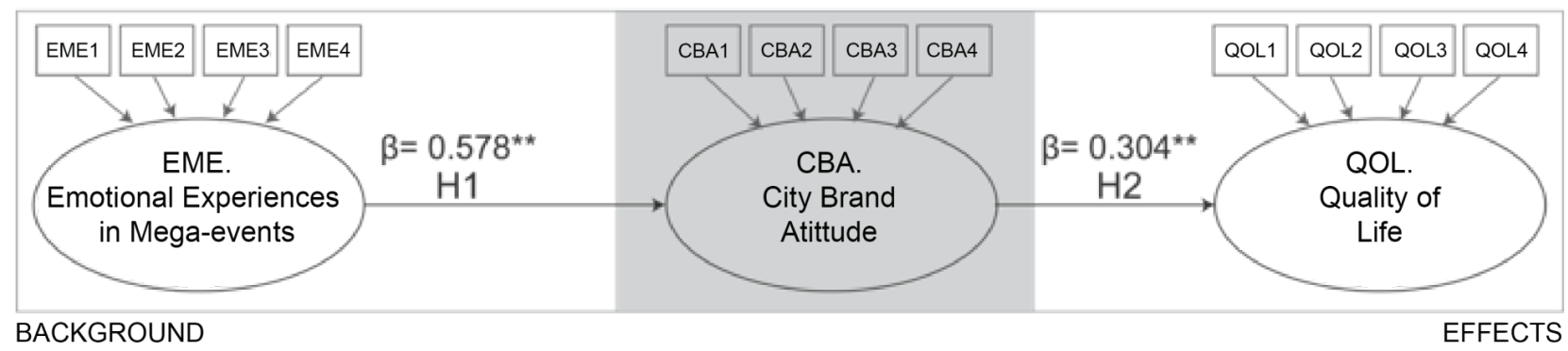

Figure 1. Solution to the proposed model.

$\mathrm{N}=398^{* *} \mathrm{p}<.01$;

$\chi^{2}(\mathrm{p})=536.523(0.0000), d f=179 ; \mathrm{NNFI}=0.900 ; \mathrm{CFI}=0.915 ; \mathrm{IFI}=0.915 ; \mathrm{RMSA}=0.071$

Source: Authors

As for the emotional experiences in mega-events, a significant and positive value as far as impact on city brand attitudes relationship is found. Indeed, the hypothesis $\mathrm{H} 1$ finds that the city brand attitudes among residents increases when emotional experiences living in mega-events
$(=0.578, \mathrm{p}<0.01)$. This hypothesis agrees with theoretical support provided in the Dolles and Söderman (2010) study, in which the experiences in the World Cup Germany 2006, enriched the city achieving recognition of the country brand with a sustainability perspective by citizens. 
Regarding the effects in terms of quality of life, the empirical study allowed us to demonstrate a significant and positive relationship between constructs city brand attitudes and quality of life $(=0.304, \mathrm{P}<0.01)$, as the $\mathrm{H} 2$ hypothesis of this research. Thus, it can be assumed that as positive city brand attitudes improve, so does the perception of quality of life among residents of a particular place. Kavaratzis (2008) had demonstrated this relationship in his study among residents of Athens during the Olympic Games in 2004, during which the Greeks developed new attitudes towards their country (city brand), which was reflected in an increase in their quality of life. This, in turn, can point to the existence of an indirect effect of emotional experiences in mega-events on the perceived quality of life among residents.

\section{Conclusions, implications and future research}

The overall proposal was intended finding was based on analyzing the role of the strategy of experiential marketing embodied in the development of events as a direct antecedent of city brand attitudes and thus demonstrate the effects produced on perceived quality of life. Thus, with regard to history, it is found that the city brand attitudes among residents can directly increase when emotional experiences living in mega-events (H1). As regards effects, it shows that, in terms of quality of life, the empirical study has demonstrated a significant and positive relationship between the constructs city brand attitudes and quality of life (H2).

In light of these results, it is concluded that this investigation has made progress in the implementation of experiential marketing channeled through the emotional experiences in mega-events, since to date there was no evidence of empirical research referenced in mega-events the characteristics of the Feria Nacional de San Marcos, Mexico.
Therefore, and from the results, public managers it intends to innovate, first, in the development of an efficient strategy for recognition of city brand through the development of megaevents, in which attendees experience pleasant emotions that result in the consolidation of a city brand strong and recognized. This will bring benefits to local residents in terms of perceived quality of life, which can be expected to result in attracting tourists and businesses triggering an interesting economic development.

As already mentioned, the attitudes derive intentions, so if you are looking to attract industries, qualified personnel or tourists to a particular city, you first must have the support of the residents themselves, i.e., their favorable city brand attitudes.

Finally, the quality of life would be the most desirable goal to live in a particular place. Research has offered positive support on the relationship between city brand attitudes and perception of quality of life. This implies, then, that a timely strategy for rulers who are interested in enhancing the quality of life of residents of a place must go through improve city brand attitudes, generating pride in where they live. To do this, it becomes a priority, providing all services at the request of citizens are most needed to live with high quality of life.

In addition, despite the results of this research, it is crucial to recognize certain weaknesses in this study, as shown in light of positive expectations for the academic community and marketing managers.

As for the sample chosen and the procedure for collecting information, they may have not been the most optimum, because sometimes informants were more immersed in the event than in answering the survey, which could have led to a response bias.

On the other hand, the measurement scales used in this study are an adaptation of other scales, and adapted from a language other than Spanish spoken in Mexico and even have been used to evaluate other events or situations and 
even before this study did not they had been used in the Mexican context.

Despite the profile of the sample was obtained, no analysis was performed to determine differences of the model based on the demographic variables collected, and it would be interesting to identify whether there is any divergence when specifying one of these variables and the initial model (assessed in this study).

Finally, once the above limitations are overcome, it may be possible to replicate this study in other contexts to test the hypotheses in different environments within mega-events with different characteristics - comparing, for example, a mega-event that was organized entirely by a local government with a mega-event organized mostly by the population, or to compare results while experiences are occurring in a sports or any other different mega-event.

\section{References}

Aaker, D. A. (1984). Strategic market management. New York: John Wiley \& Sons.

Anholt, S. (2007). Competitive identity. London: Palgrave Macmillan.

Arnold, M. J., \& Reynolds, K. (2003). Hedonic shopping motivations. Journal of Retailing, 79(2), 77-95.

Ashworth, G., \& Voogd, H. (1990). Selling the city. London: Belhaven.

Atkinson, G., Mourato, S., Szymanski, S., \& Ozdemiroglu, E. (2008). Are we willing to pay enough to 'back the bid'?: Valuing the intangible impacts of London's bid to host the 2012 Summer Olympic Games. Urban Studies, 45(2), 419-444.

Baker, D. A., \& Palmer, R. J. (2006). Examining the effects of perceptions of community and recreation participation on quality of life. Social Indicators Research, 75(3), 395-418.
Bentler, P. M. (2005). EQS 6 structural equations program manual. Encino, CA: Multivariate Software.

Carmines, E. G., \& Zeller, R. A. (1979). Reliability and validity assessment (Quantitative Applications in the Social Sciences Series, Vol. 17). Thousand Oaks, CA: Sage Publications.

Cespedes, F. V. (1993). Ethical issues in distribution. In N. C. Smith \& J. Quelch (Eds.), Ethics in marketing (pp. 473-490). Illinois: Irwin Homewood.

Cifras (2010). Cuadernos de información estadistica del Estado de Aguascalientes. Mayo-Junio. Aguascalientes: Cifras.

Cuenca Cabeza, M. (2000). Ocio humanista: Dimensiones y manifestaciones actuales del ocio (Documento de Estudios de Ocio, n. 16). Bilbao, Espanha Universidad de Deusto, España.

Curi, M., Knijnik, J., \& Mascarenhas, G. (2011). The Pan American Games in Rio de Janeiro 2007: Consequences of a sport mega-event on a BRIC country. International Review for the Sociology of Sport, 46(2), 40-156.

Day, G. S. (1984). Strategic market planning. St Paul, MN: West Publishing.

Dinnie, K. (2004). Place branding: Overview of an emerging literature. Place Branding, 1(1), 106-110.

Dolles, H., \& Söderman, S. (2010). Addressing ecology and sustainability in mega-sporting events: The 2006 football World Cupin Germany. Journal of Management \& Organization, 16(4), 587-600.

Fitchett, J. (2005). Consumers as stakeholders: Prospects for democracy in marketing theory. Business Ethics, Euro Review, 4(1), 14-27. 
Fornell C, \& Larker D. (1981). Evaluating structural equation models with unobservable variables and measurement error. Journal of Marketing Research, 18(3), 39-50.

Fayers, P. M., Hand, D. J., Bjordal, K., \& Groenvold, M. (1997). Causal indicators in quality of life research. Quality of life research, 6(5), 393-406.

Freyer, W. (2000). Event-Management im Tourismus - Kulturveranstaltungen und Festivals als touristische Leistungsangebote. In A. Dreyer (Ed.), Kulturtourismus (pp. 211-242). München: Oldenbourg.

Friedman, A., \& Miles, S. (2002). Developing stakeholder theory. Journal of Management Studies, 39(1), 1-21.

Getz, D. (1997). Event management \& event tourism. New York: Cognizant Communication.

Hirschman, E. C., \& Sheth, J. N. (1985a.). Cognitive processes in experiential consumer behavior. In Agdish N. Sheth (Ed.), Research in Consumer Behavior: A research annual (1, 67-102). Greenwich, CT: JAI Press.

Hirschman, E. C. (1985b). Dual consciousness and altered states: Implications for consumer research. Journal of Business Research, 13(3), 223234.

Hirschman, E. C., \& Holbrook M. C. (1982). Hedonic consumption: Emerging concepts, methods and propositions. Journal of Marketing, 46(3), 92-101.

Holbrook, M. B. (1986). Emotion in the consumption experience: Toward a new model of the human consumer. In The role of affect in consumer behavior: Emerging theories and applications, (408-410). Robert A. Peterson, Wayne D. Hoyer, and William R. Wilson (Eds.). Lexington, MA: D.C. Heath.
Holbrook, M. B., \& Hirschman, E. C. (1982). The experiential aspects of consumption: Consumer fantasies, feelings, and fun. Journal of Consumer Research, 9(2), 132-140.

Holbrook, M. B., \& Kim, P. C. (1985). Quality and value in the consumption experience: Phaedrus rides again. In J. Jacob, \& J. C. Olson (Eds.), Perceived Quality: How Consumers View Stores and Merchandise (p. 31 -57). Lexington, MA: D.C. Heath.

Ibrahim, M. F., \& Wee, N. C. (2002). The importance of entertainment in the shopping center experience: Evidence from Singapore. Journal of Real Estate Portfolio Management, 8(3), 239-254.

Jessop, B., \& Sum, N.-L. (2000). An entrepreneurial city in action: Hong Kong's emerging strategies in and for (Inter-) Urban Competition. Urban Studies, 37(12), 2287-2313.

Kao, Y., Huang, L., \& Yang, M. (2007). Effects of experiential elements on experiential satisfaction an loyalty intentions: A case study of the super basketball league in Taiwan. International Journal of Revenue Management, 1(1), 79-96.

Kavaratzis M. (2004). From city marketing to city branding: Towards a theoretical framework for developing city brands. Place Branding, 1(1), 58-73.

Kavaratzis, M. (2008). From city marketing to city branding: An interdisciplinary analysis with reference to Amsterdam, Budapest and Athens (Doctoral Thesis). Rijksuniversiteit Groningen: Groningen, Netherlands.

Kilbourne W., Mcdonagh P., \& Prothero A. (1997). Sustainable consumption and the quality of life: A macromarketing challengeto the dominant social paradigm. Journal of Macromarketing. 17(1), 4-24. 
Kotler, P., Nebenzahl, I. D., Lebedenko, V., Rainisto, S., Gertner, D., Clifton, R. \& Van Ham, P. (2004). Where is place branding heading? Place Branding, 1(1), 12-35.

Küster, I., Vila, N. Aldás, J. Y., \& Rodríguez, C. (2009). Efecto del patrocinio de la Copa Amercia en las percepciones de Luis Vuitton: Una perspectiva internacional. Universia Business Review, (22).

La Roca, F., \& Ferrer, G. (2004). Valencia y Barcelona ante el desarrollo sostenible. ¿Sustentabilidad o marketing ambiental. Centre d'Estudis Politics i Socials Ágora-Revista de Ciencias Sociales, 11, 53-81.

Law, C. M. (1993). Urban tourism, attracting visitors to large cities. London: WM.

Leonardsen, D. (2007). Planning of mega events: Experiences and lesson. Planning Theory and Practice, 8(1), 11-30.

Lynch, K. (1960). The image of the city. Cambridge: MIT Press.

Mathwick, C., Malhotra, N., \& Rigdon., E. (2001). Experiential value: Conceptualization, measurement and application in the catalog and Internet shopping environment. Journal of Retailing, 77, 39 - 56.

Merrilees, B. \& Miller, D. \& Herington, C. (2009). Antecedents of residents' city brand attitudes. Journal of Business Research, 62(3), 362-367.

Mo, C., Howard, D. R. \& Havitz, M. E. (1993). Testing an international tourist role typology. Annals of Tourism Research, 20(2), 319-335.

Naylor, Gillian, Kleiser, Susan B., Baker, Julie, \& Yorkston, Eric. (2008). Using transformational appeals to enhance the retail experience. Journal of Retailing, 84(1), 49-57.
Nunnally, J. C. \& Bernstein, I. H. (1994). Psychometric Theory. 3rd. ed. New York: McGrawHill.

Pascual-Esteve, J. M. (1999). La estrategia de las ciudades: Los planes estratégicos como instrumento: métodos, técnicas y buenas prácticas. Barcelona: Diputació de Barcelona.

Pennings, J. (1982). The urban quality of life and entrepreneurship. Academy of Management Journal, 25(1), 63-79.

Perry, J., \& Felce, D. (1995). Objective assessment of quality of life: How much do they agree with each other? Journal of Community and Applied Social Psychology, 15, 1-19.

Pitt, Leyland, Parent, Michael, Berthon, Pierre, \& Steyn, Peter G. (2010). Event sponsorship and ambush marketing: Lessons from the Beijing Olympics. Business Horizons, 53(3), 281-290.

Ponsonby-Mccabe, S., \& Boyle, E. (2006). Understanding brands as experiential spaces: Axiological implications for marketing strategists. Journal of Strategic Marketing, 14, 175 - 189.

Puccinelli, N. M., Goodstein, R. C., Grewal, D., Price, R., Raghubir, P, \& Stewart, D. (2009). Customer experience management in retailing: Understanding the buying process. Journal of Retailing, 85(1), 15-30.

Ritchie, J. R. B., \& Yangzhou, J. (1987). The role and impact of mega-events and attractions on national and regional tourism: A conceptual and methodological overview. In The Role and Impact of Mega-Events and Attractions on Regional and National Tourism Development, 28, 17-58.

Roche, M. (1994). Mega-events and urban policy. Annals of Tourism Research, 21(1), 1-19.

Roche, M. (2003). Mega-events, time and modernity: On time structures in global society. Time and Society. 12(1), 99-126. 
Rogerson, R. J. (1988). Quality of life in British Cities: A summary report. Universidad de Glasgow: Escocia.

Ryan, M., \& Mizerski, K. (2010). Place branding for sustainable futures: A case study. Place Branding and Public Diplomacy, 6(1), 49-57.

Schmitt, B. (1999). Experiential Marketing. Journal of Marketing Management, 15(1), 53-67.

Sirgy, M. J. (2001). Handbook of quality-of-life research: An ethical marketing perspective. Kluwer Academic Publisher, 8.

Sirgy, M. J., \& Lee, D-J. (1996). Setting socially responsible marketing objectives: A quality-of-life approach. European Journal of Marketing, 30(5), 20-34.

Sirgy, M. J. (1991). Special issue: quality of life. Journal of Business Research, 23(1), 126.

Sirgy, M. J., Samli, A. C., \& Meadow, H. (1982). The interface between quality-of-life and marketing: A theoretical framework. Journal of Macromarketing and Public Policy, 1, 69-84.

Smyth, H. (1994). Marketing the city: The role of flagship developments in urban regeneration. London: E \& F N Spon.

Sola, F. E. (1998). The impact of mega-events. Annals of Tourism Research, 25(1), 241-245.

Tatsiopoulos, I., \& Tziralis, G. (2007). New, post-Olympic Athens, in laboratory of political communication: University of Athens, about brand
Greece, coordinator Metaxas A-JD. Athens: General Secretariat of Information.

Tauber, E. M. (1972). Why Do People Shop? Journal of Marketing. 36, 46-59.

Verhoef, P. C, Lemon, K. N., Parasuraman, A., Roggeveen, A., Tsiros, M., \& Schlesinger, L. A. (2009). Customer experience creation: Determinants, dynamics and management strategies. Journal of Retailing, 85(1), 31-41.

Virgo, B., \& De Chernatony, L. (2006). Delphic brand visioning to align stakeholder buy-in to the city of Birmingham brand. Journal of Brand Management, 13(6), 379-92.

Ward, S. (1998). Selling places: The marketing and promotion of towns and cities 1850-2000. London: Spon Press.

Whelan, S., \& Wohlfiel, M. (2006). Communicating brands through engagement with "lived" experiences. Journal of Brand Management, 13(4/5), 313-329.

Zanger, C., \& Sistenich, F. (1996). Eventmarketing: Bestandsaufnahme, Standortbestimmung und ausgewähtle theoretische Anätze zur Erklärung eines innovativen Kommunikationsinstruments. Marketing. Zeitschrift für Forshung un Praxis, 18(4), 233-242.

Zenker, S., Petersen, S., \& Aholt, A. (2009). Development and implementation of the citizen satisfaction index (CSI): Four basic factors of citizens' satisfaction. Universität Hamburg, Tor zur Wel t der Wissenschaft: Hamburg. 


\section{About the authors:}

1. Natalia Vila López, PhD in Economics and Business from University of Valencia, Faculty of Economics. Email: natalia.vila@uv.es.

2. Ines Kuster Boluda, PhD in Economics and Business from Universidad de Valencia, Faculty of Economics. Email: ines.kuster@uv.es.

3. J. Trinidad Marín Aguilar, PhD in Marketing from the University of Valencia, Faculty of Economics. Email: trino.mrn@hotmail.com.

\section{Contribution of each author:}

\begin{tabular}{lccc}
\hline Contribution & Natalia Vila López & Inés Kuster Boluda & J. Trinidad Marín Aguilar \\
\hline 1. Definition of research problem & $\sqrt{ }$ & $\sqrt{ }$ & $\sqrt{ }$ \\
2. Development of hypotheses or research questions & $\sqrt{ }$ & & $\sqrt{ }$ \\
(empirical studies) & & & \\
3. Development of theoretical propositions (theoretical & & $\sqrt{ }$ & \\
Work) & $\sqrt{ }$ & $\sqrt{ }$ & $\sqrt{ }$ \\
4. Theoretical foundation/ Literature review & $\sqrt{ }$ & $\sqrt{ }$ \\
5. Definition of methodological procedures & & $\sqrt{ }$ & $\sqrt{ }$ \\
6. Data collection & & $\sqrt{ }$ & $\sqrt{ }$ \\
7. Statistical analysis & $\sqrt{ }$ & $\sqrt{ }$ & $\sqrt{ }$ \\
8. Analysis and interpretation of data & $\sqrt{ }$ & $\sqrt{ }$ & \\
9. Critical revision of the manuscript & $\sqrt{ }$ & & \\
10. Manuscript Writing & & & \\
11. Other (please specify which) Revision of the paper & $\sqrt{ }$ & & \\
\hline
\end{tabular}

